\section{Sosialisasi Pengenalan Zakat Fitrah Terhadap Santriwati Pondok Pesantren Madinatul Quran Desa Betung, Ogan Ilir}

\author{
Saprida \\ Program Studi Ekonomi Syariah STEBIS IGM Palembang \\ Email : saprida@stebisigm.ac.id
}

\begin{abstract}
This community service activity discusses the introduction of zakat fitrah both from the understanding of zakat fitrah, the mandatory requirements for zakat fitrah, the time to pay zakat fitrah, mustahiq zakat, types of objects issued for zakat fitrah and the wisdom of zakat fitrah. The purpose of this community service activity is to provide an introduction to zakat fitrah for students of the Madinatul Quran Islamic Boarding School in Betung Ogan Ilir Village with the hope that the socialization participants can understand the obligation of zakat fitrah for all Muslims who have excess assets. Socialization participants can also find out that zakat can bring closer relationships of affection and love between poor and rich people. Zakat can also cleanse oneself from stingy and despicable morals, and educate oneself to be noble and generous by making it a habit to pay mandates to people who are entitled to receive it.
\end{abstract}

Keywords : Socialization, Mustahiq, Zakah Fitra

\begin{abstract}
Abstrak
Kegiatan pengabdian masyarakat ini membahas tentang pengenalan zakat fitrah baik dari pengertian zakat fitrah, syarat-syarat wajib zakat fitrah, waktu membayar zakat fitrah, mustahiq zakat, jenis benda yang dikeluarkan untuk zakat fitrah dan hikmah zakat fitrah. Tujuan kegiatan pengabdian masyarakat ini memberikan pengenalan tentang zakat fitrah terhadap santriwati Pondok Pesantren Madinatul Quran Desa Betung Ogan Ilir dengan harapan peserta sosialisasi bisa memahami akan kewajiban zakat fitrah bagi semua orang Islam yang mempunyai kelebihan harta. Peserta sosialisasai juga bisa mengetahui bahwa zakat dapat mendekatkan hubungan kasih sayang dan cinta-mencintai antara orang miskin dan orang kaya. Zakat juga bisa membersihkan diri dari sifat kikir dan akhlak yang tercela, serta mendidik diri agar bersifat mulia dan pemurah dengan membiasakan membayarkan amanat kepada orang yang berhak menerimanya.
\end{abstract}

Kata Kunci: $\quad$ Sosialisasi, Mustahiq, Zakat Fitrah

\section{Pendahuluan}

Salah satu sunnatullah yang sudah menjadi ketentuan Yang Maha Kuasa adalah perbedaan yang terdapat pada setiap diri manusia. Setiap orang lahir dan hidup di dunia memiliki kondisi tersendiri yang berbeda dengan orang lain. Perbedaan ini mencakup semua aspek, mulai dari budaya, sosial, kultur dan lain sebagainya. Salah satu perbedaan ini adalah perbedaan kondisi ekonomi. Sebagian manusia, ada yang dititipi oleh Allah harta sehingga menjadi orang kaya dan berada, dan sebagian lagi ada yang dicoba dengan kekurangan dan hidup miskin. Semua ini bukannya tanpa tujuan. Ini adalah rahasia Allah SWT. untuk 
menyadarkan manusia menyadari bahwa dirinya bukanla apa-apa. Selain itu, Allah ingin menguji, apakah manusia itu mampu mengoptimalkan segala potensi kebaikan yang diberikan kepadanya atau tidak. Dalam Al-Qur'an, Allah Swt. berfirman :

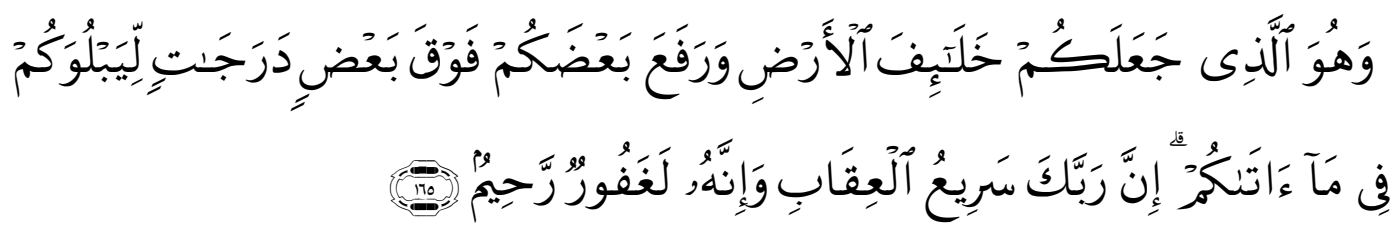

Artinya; Dan Dia lah yang menjadikan kamu penguasa-penguasa di bumi dan Dia meninggikan sebahagian kamu atas sebahagian (yang lain) beberapa derajat, untuk mengujimu tentang apa yang diberikan-Nya kepadamu. Sesungguhnya Tuhanmu Amat cepat siksaan-Nya dan Sesungguhnya Dia Maha Pengampun lagi Maha Penyayang (Mujahidin, 2014: 66).

Perbedaan yang ada ini dalam banyak hal sering menjadi masalah dan prolem bagi manusia. Dalam kehidupan sehari-hari, timbul gejolak-gejolak akibat kesenjangan diantara manusia yang sulit dikontrol. Orang kaya yang dititipi harta melimpah tidak menjalankan tugasnya dalam menolong fakir miskin yang membutuhkan. Sebagian sebagian orang malah memanfaatkan kekayaan tersebut untuk mengeksploitasi harta sebanyak-banyaknya untuk kepentingan sendiri. Akhirnya, kesenjangan dan gejolak tak dapat dihindarkan lagi. Karena itu Allah menurunkan syariat-Nya bagi manusia guna menciptakan kesejahteraan dan kedamaian di bumi dalam kondisi tersebut. Hal inilah yang biasa kita sebut dengan Al-Islam. Artinya, hanya dengan Islam saja manusia akan mampu mencapai kebahagian dalam hidup mereka. Akal pikiran dan ilmu pengetahuan manusia yang terbatas tidak akan mampu menciptakan sebuah solusi yang lebih baik dari pada solusi yang dibuat oleh Pencipta manusia itu sendiri.

Salah satu ajaran dalam Islam yang bertujuan mengatasi kesenjangan dan gejolak sosial tersebut adalah zakat. Zakat yang menjadi salah satu rukun penyangga tegaknya Islam serta kewajiban bagi pemeluknya membawa misi memperbaiki hubungan horizontal antara sesama manusia yang pada akhirnya mampu mengurangi gejolak akibat problematika kesenjangan dalam hidup mereka. Selain itu, zakat juga dapat memperkuat hubungan vertikal manusia dengan Allah, karena Islam menyatakan bahwa zakat merupakan bentuk pengabdian (ibadah) kepada Yang Maha Kuasa (Mujahidin, 2014: 67).

\section{Metode Pengabdian}

1. Metode Pelaksanaan

Rangkaian kegiatan pengabdian masyarakat adalah sebagai berikut:

1) Bentuk Kegiatan

Bentuk kegiatan yang dilakukan dalam sosialisasi tersebut adalah :

$>$ Pemaparan materi tentang zakat fitrah.

$>$ Pemahaman dan tanya jawab tentang pelaksanaan zakat fitrah yang benar menurut ajaran Islam.

2) Tempat Kegiatan 
Adapun tempat kegiatan atau lokasi kegiatan dilaksanakan di Masjid Pondok Pesantren Madinatul Quran desa Betung Ogan Ilir.

3) Proses Kegiatan

Adapun proses kegiatan dilaksanakan dalam waktu 2 hari pada hari Sabtu dan Minggu mulai tanggal 01-02 Agustus 2020. Adapun kegiatan yang dilakukan selama kegiatan berlangsung adalah sebagai berikut :

a. Tanggal 01 Agustus 2020 : berikut :

Adapun kegiatan yang dilakukan pada pertemuan ke-1 adalah sebagai

1) Registrasi peserta

2) Penyampaian materi sesi I oleh Saprida, M.H.I. dengan judul materi pengertian zakat fitrah dan syarat zakat fitrah.

3) Penjelasan dalil tentang zakat fitrah dan waktu-waktu membayar zakat fitrah disampaikan oleh Saprida, M.H.I.

b. Tanggal 02 Agustus 2020:

Dilaksanakan pada pertemuan ke-2 adalah sebagai berikut :

1) Menyampaikan materi sesi II dilakukan oleh Saprida, M.H.I dengan judul materi mustahiq zakat fitrah.

2) Penjelasan jenis-jenis benda yang dikeluarkan untuk zakat fitrah dan hikmah zakat fitrah, dibawakan oleh Saprida, M.H.I

3) Tanya jawab tentang zakat fitrah.

4) Doa dan penutup yang dibawakan oleh saprida, M.H.I.

\section{Waktu Kegiatan dan Materi Pokok dalam Kegiatan}

Pelaksanaan kegiatan dilakukan dalam waktu dua hari pada hari Sabtu dan Minggu Adapun jadwal pelaksanaannya adalah sebagai berikut :

Tanggal 01 Agustus 2020

\begin{tabular}{|l|l|l|}
\hline \multicolumn{1}{|c|}{ Waktu } & \multicolumn{1}{|c|}{ Materi } & \multicolumn{1}{c|}{ Narasumber } \\
\hline $09.00-09.30$ & - Registrasi peserta & - Mahasiswi \\
\hline $09.30-10.00$ & - Pembukaan & - Choiriyah, S.H.I.,M.Pd.I. \\
\hline $10.00-11.00$ & $\begin{array}{l}\text { Materi: } \\
- \text { Pengertian zakat fitrah }\end{array}$ & - Saprida, M.H.I \\
\hline $11.00-12.00$ & - Syarat zakat fitrah & - Saprida, M.H.I \\
\hline $12.00-13.00$ & \multicolumn{2}{|c|}{ ISOMA } \\
\hline $13.00-14.00$ & $\begin{array}{l}\text { Materi: } \\
\text { - Dalil tentang zakat fitrah }\end{array}$ & - Saprida, M.H.I \\
\hline $14.00-15.00$ & - Tanya jawab zakat fitrah & - Saprida, M.H.I \\
\hline
\end{tabular}

Tanggal 02 Agustus 2020

\begin{tabular}{|c|l|l|}
\hline \multicolumn{1}{|c|}{ Waktu } & \multicolumn{1}{|c|}{ Materi } & \multicolumn{1}{c|}{ Narasumber } \\
\hline $09.00-10.30$ & $\begin{array}{l}\text { Materi: } \\
- \text { Waktu membayar zakat fitrah }\end{array}$ & - Saprida, M.H.I \\
\hline $10.30-12.00$ & $\begin{array}{l}- \text { Mustahiq zakat fitrah dan } \\
\text { jenis benda yang dizakatkan }\end{array}$ & - Saprida, M.H.I \\
\hline $12.00-13.00$ & \multicolumn{2}{|c|}{ ISOMA } \\
\hline $13.00-14.00$ & $\begin{array}{l}\text { Materi: } \\
- \text { Hikmah zakat fitrah }\end{array}$ & - Saprida, M.H.I \\
\hline
\end{tabular}




\begin{tabular}{|l|l|l|}
\hline $14.00-15.00$ & - Doa dan penutup & - Choiriyah, S.H.I.,M.Pd.I.
\end{tabular}

Total durasi pelaksanaan pengabdian pada masyarakat untuk masing-masing pelaksana adalah :

\begin{tabular}{|c|l|c|l|c|}
\hline No & \multicolumn{1}{|c|}{ Nama } & NIDN/NPM & \multicolumn{1}{|c|}{ Status } & Durasi \\
\hline 1 & Saprida, M.H.I & 2114118401 & Dosen Ekonomi & 36 Jam \\
\hline 2 & Choiriyah, S.H.I.,M.Pd.I. & 2123068201 & Dosen Perbankan & 1 Jam \\
\hline 3 & Indah Syawalina & 201701015 & Mahasiswi & 1 Jam \\
\hline
\end{tabular}

\section{Hasil dan Pembahasan}

1. Materi Sosialisasi

a. Pengertian Zakat Fitrah

Zakat fitrah secara etimologi yaitu zakat yang sebab diwajibkannya adalah futur (berbuka puasa) pada bulan Ramadhan. Sedangkan secara terminologi yaitu zakat yang dikeluarkan berdasarkan jumlah atau anggota keluarga, perempuan dan laki-laki, kecil maupun dewasa wajib mengeluarkan zakat fitrah pada bulan Ramadhan. Zakat fitrah diwajibkan pada tahun kedua Hijrah, yaitu tahun diwajibkan puasa bulan Ramadhan untuk mensucikan orang yang berpuasa dari ucapan kotor dan perbuatan yang tidak ada gunanya, untuk memberi makanan pada orang-orang miskin dan mencukupkan mereka dari kebutuhan yang diperlukan. Zakat fitrah merupakan zakat yang berbeda dari zakat lainnya, karena zakat fitrah merupakan zakat pada individu, sedangkan zakat lainnya merupakan zakat pada harta. Karenanya tidak disyaratkan pada zakat fitrah, apa yang disyaratkan pada zakat harta, seperti memiliki nisab (Saprida, 2015: 57)

Zakat fitrah diwajibkan pada bulan Sya'ban tahun kedua Hijriyah. Zakat fitrah diwajibkan bagi semua orang baik kecil maupun dewasa, laki-laki atau perempuan sebanyak satu sha' bagi orang Islam, ketentuan kewajiban zakat fitrah ini dapat dilihat dalam Al-Quran dan Hadist sebagai berikut:

1) Q.S. Al-A'la ayat 14-15:

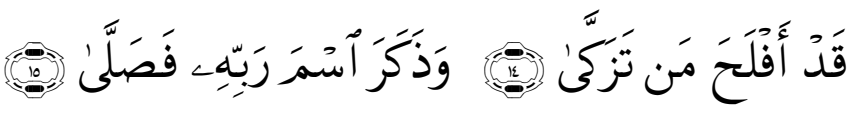

Artinya: Sesungguhnya beruntunglah mereka yang menyucikan diri (dengan mengeluarkan zakat fitrah) dan yang menyebut nama Tuhannya(takbir, tasbih) lalu mengerjakan shalat (idul fitri) (Fakhruddin, 2008: 40).

2) Hadis Bukhari dan Muslim :

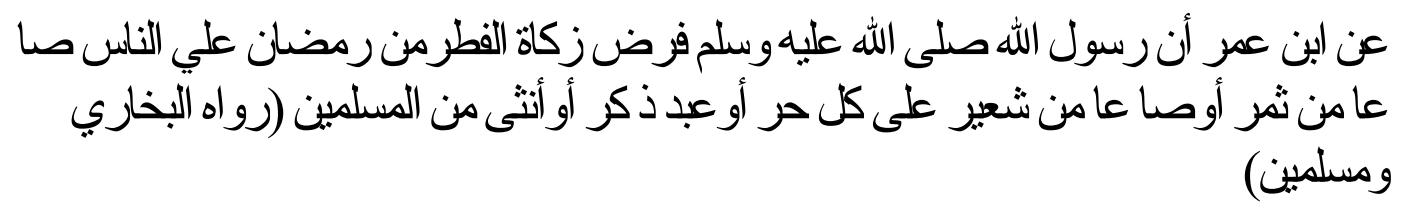

Artinya: "Ibnu Umar melaporkan bahwa Rasulullah SAW mewajibkan zakat fitri satu sha' kurma kering atau bur atas budak dan orang merdeka, laki-laki maupun perempuan, tua dan muda diantara kaum muslimin"'(Chaudhry, 2016: 93).

b. Syarat-syarat Wajib Zakat Fitrah

Syarat-syarat orang wajib membayar zakat fitrah adalah : 
1) Islam. Orang yang tidak beragama Islam tidak wajib membayar zakat fitrah.

2) Lahir sebelum terbenam matahari pada hari penghabisan bulan Ramadhan. Anak yang lahir sesudah terbenam matahari tidak wajib fitrah. Orang yang nikah sesudah terbenam matahari tidak wajib membayarkan fitrah istrinya yang baru dinikahinya.

3) Dia mempunyai kelebihan harta dari keperluan makanan untuk dirinya sendiri dan untuk yang wajib dinafkahinya, baik manusia ataupun binatang, pada malam hari raya dan siang harinya. Orang yang tidak mempunyai kelebihan harta tidak wajib membayar zakat fitrah karena takut tidak dapat memenuhi keluarganya sendiri (Barkah, dkk. 2020: 54).

\section{c. Waktu Membayar Zakat Fitrah}

Waktu-waktu pembayaran zakat fitrah dilaksanakan adalah sebagai berikut :

1) Waktu yang diperbolehkan, yaitu dari awal Ramadhan sampai hari penghabisan Ramadhan.

2) Waktu wajib, yaitu mulai terbenam matahari penghabisan Ramadhan.

3) Waktu yang lebih baik (sunnah), yaitu dibayar sesudah sholat shubuh.

4) Waktu makruh, yaitu membayar zakat fitrah sesudah sholat hari raya, tetapi sebelum terbenam matahari pada hari raya.

5) Waktu haram, lebih telat lagi yaitu dibayar sesudah terbenam matahari pada hari raya (Saprida, 2015: 58)

\section{d. Mustahiq Zakat Fitrah}

Orang-orang yang berhak menerima zakat hanya mereka yang telah ditentukan oleh Allah SWT. Dalam Al-Qur'an mereka itu terdiri dari delapan golongan. Firman Allah SWT.

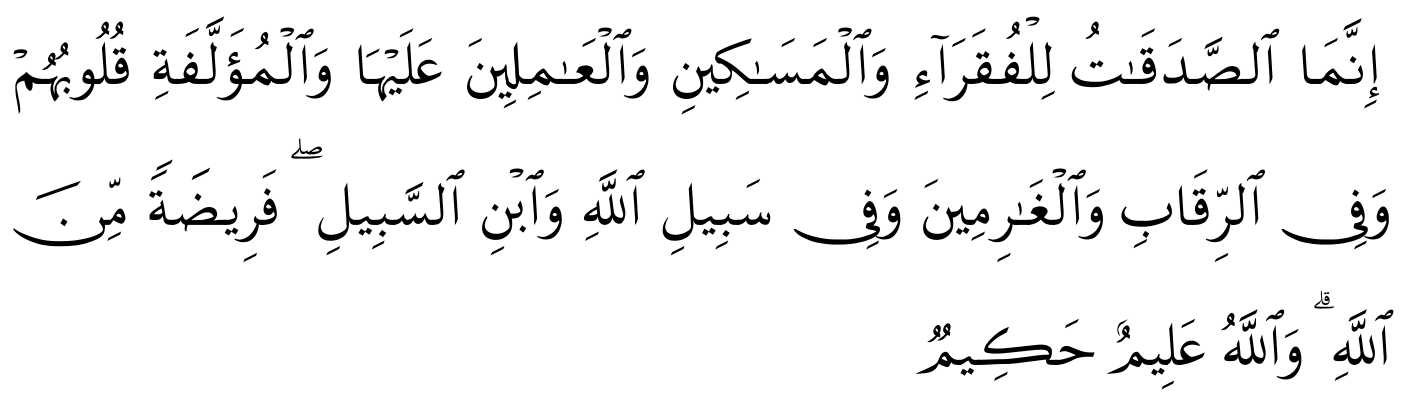

Artinya : "Sesungguhnya zakat-zakat itu, hanyalah untuk orang-orang fakir, orang-orang miskin, pengurus-pengurus zakat, para mu'allaf yang dibujuk hatinya, untuk (memerdekakan) budak, orang-orang yang berhutang, untuk jalan Allah dan untuk mereka yuang sedang dalam perjalanan, sebagai suatu ketetapan yang diwajibkan Allah, dan Allah Maha mengetahui lagi Maha Bijaksana” (Q. S. At-Taubah : 60) (Heykal. 2013: 299).

Ayat ini menunjukkan bahwa zakat itu wajib diberikan kepada asnaf yang delapan yaitu orang-orang fakir, orang-orang miskin, pengurus-pengurus zakat, para mu'allaf yang dibujuk hatinya, hamba sahaya, orang yang berhutang di jalan Allah, sabilillah dan orang-orang yang sedang dalam perjalanan. Dengan penjelasan sebagai berikut :

1) Fakir 
Fakir ialah orang yang tidak memiliki harta dan tidak memiliki pekerjaan dan penghasilan yang dapat memenuhi kebutuhan pokok diri dan keluarga berupa pangan, pakaian, dan perumahan (Rozalinda, 2016: 262).

2) Miskin

Miskin ialah orang yang mempunyai harta atau mata pencaharian, namun belum mencukupi keperluannya sehari-hari, baik ia meminta-minta maupun tidak.

3) Amil

Amil ialah orang yang ditunjuk oleh seorang pemimpin atau wakilnya dan dijadikan sebagai petugas untuk mengumpulkan zakat. Amil zakat disyaratkan merdeka, lelaki, muslim mukalaf karena memungut dan mengumpulkan zakat merupakan kekuasaan sementara kekuasaan mensyatarkan hal-hal tersebut. Amil boleh berasal dari orang miskin atau orang kaya.

4) Muallaf

Muallaf adalah orang laki-laki muslim yang keislamannya masih lemah namun memiliki pengaruh terhadap kaumnya, jika masih kafir, ia tidak berhak menerima zakat meskipun ia ingin masuk Islam.

5) Budak

Budak yaitu seorang muslim yang menjadi budak lalu dibeli dari harta zakat dan dibebaskan di jalan Allah atau seorang budak muslim yang ingin memerdekakan dirinya lalu diberi dari harta zakat agar menjadi orang-orang merdeka.

6) Gharim (Orang yang berhutang)

Gharim adalah orang yang memiliki hutang yang terdesak mencari hutangan untuk kebutuhan-kebutuhan pribadi ataupun karena kebutuhan-kebutuhan sosial maupun agama.

7) Fi sabilillah

Fisabilillah adalah amalan yang dapat menyampaian pada keridhoan Allah dan Surga nya. Terkhusus dengan jihad untuk meninggkan agama Allah. maka orang yang ikut berperang dijalan Allah diberi zakat meskipun orang kaya.

8) Ibnu Sabil

Ibnu Sabil adalah orang yang menempuh perjalalanan jauh yang sudah tidak punya harta lagi. Perjalanan yang dimaksukan adalah perjalanan dalam rangka ketaatan kepada Allah bukan untuk maksiat. Termasuk dalam kategori ibnu sabil diantaranya orang yang diusir dari negaranya dipisahkan dari harta miliknya secara pakasa dan minta suaka politik (Rozalinda, 2016: 265).

\section{e. Jenis Benda yang Dikeluarkan untuk Zakat Fitrah}

Jenis makanan untuk zakat fitrah telah ditetapkan yaitu kurma kering, sya'ir, kurma basah, dan susu kering yang tidak dibuang buihnya. Sebagian riwayat menetapkan tentang gandum, dan sebagian lagi biji-bijian. Golongan Maliki dan Syafi'i berpendapat, bahwah jenis makanan itu bukan bersifat ta'abbudi dan tidak dimaksudkan bendanya sendiri, sehingga wajib bagi Muslim mengeluarkan zakat fitrah dari pokok makanan negerinya. Menurut satu pendapat, dari makanan pokok orang itu. Menurut golongan Syafi'i, sebagaimana dikemukakan dalam Al-Wasith bahwa yang dipandang dalam 
memberikan zakat fitrah yaitu makanan pokok penduduk pada waktu wajib zakat fitrah, bukan sepanjang tahun, ia berkata dalam alwajis : "Yaitu makanan pokok penduduk pada waktu hari Raya Fitrah".

Golongan Maliki mensyaratkan, bahwa makanan pokok itu harus yang termasuk sembilan asnaf, sebagaimana ditetapkan mereka yaitu : sya'ir, kurma basah, kurma kering, gandum, biji-bijian, salt, padi, susu kering dan keju. Apabila terdapat jelas yang sembilan ini atau sebagiannya, atau bersamaan dalam menguatkannya, maka boleh dipilih salah satunya untuk dikeluarkan, apabilah salah satunya yang dianggap paling pokok maka harus itulah yang dikeluarkan untuk berzakat. Apabila seluruh atau sebagiannya terdapat, sedangkan yang dijadikan makanan pokok itu yang lain, maka boleh dipilih apa yang akan dikeluarkannya (Barkah, dkk. 2020: 57).

Terhadap perincian dan pejelasan tersebut tidak ditemukan dalil yang bisa dijadikan sandaran, sehingga sebagian Ulama' menyatakan :"Apabila yang dijadikan makanan pokok itu bukan dari jenis yang sembilan itu, maka keluarkanlah apa yang menjadi makanan pokoknya, walaupun terdapat makanan yang sembilan itu atau sebagiannya". Yang dimaksudkan makanan yang menguatkan atau makanan pokok, yaitu makanan yang dimakan di waktu pagi dan petang, baik pada masa subur maupun pada masa sulit, bukan yang dimakan pada masa sulit saja. Atas dasar itu, maka para Ulama' memperbolehkan mengeluarkan daging, susu maupun yang lain, Selama itu menguatkan dan dikeluarkan berdasarkan timbangan, ataupun terhadap tepung, para Ulama' berbeda pendapat.

Golongan Maliki dalam hal ini mengemukakan suatu masalah yaitu jika seseorang mempunyai makanan pokok yang lebih rendah dari makanan pokok penduduk di negaranya, dapat disimpulkan jika makanan pokoknya yang lebih rendah dari makanan pokok penduduk di negeri itu, karena ketidakmampuannya, maka hal itu sah berdasarkan kesepakatan para Ulama'. Akan tetapi jika karena kebatilan, maka berdasarkan kesepakatan Ulama', hal itu tidak sah. Dan jika mengurangi makanan pada dirinya atau karena kebiasaannya seperti orang desa memakan sya'ir, di kota yang penduduknya memakan gandum, maka dalam hal ini terdapat perbedaan pendapat ulama' tetapi yang paling kuat adalah pendapat yang menganggap cukup.

Menurut golongan Syafi'i, biji-bijian dan buah-buahan yang wajib dikeluarkan zakatnya sepersepuluh, yaitu makanan pokok pada waktu biasa, bukan pada waktu darurat, maka pantas untuk dikeluarkan zakat fitrah dengan itu. Menurut haul Kadim Imam Syafi' i, bahwa tidak diperbolehkan mengeluarkan zakat fitrah dari kacang kedelai, dan kacang adas. Pendapat yang pertama dan mazhab yang termasyhur. Sedangkan untuk masalah zakat susu kering terjadi perbedaan, menurut Imam Nawawi mengeluarkan zakat fitrah dengan susu itu diperbolehkan karena sahihnya hadist tanpa ada yang membantah. Menurut pendapat yang paling kuat bahwa susu dan keju yaitu semakna dengan itu, akan tetapi mereka berpendapat bahwa tidak mencukupi untuk zakat fitrah, keju yang sudah hilang buihnya seperti tidak mencukupi keju yang sudah asin, yang karena banyak garamnya, hilanglah keaslian rasanya dianggap seperti itu adalah biji-bijian yang direndam atau sudah dijemur. Sebab dianggap sah, biji-bijian yang sudah lama walaupun harganya murah selama belum berubah rasa dan rupanya. Dan dianggap tidak sah, bila yang dikeluarkan itu harganya, sebagian Ulama' berpendapat, bahwa hal itu sah karena tujuannya untuk mengenyangkan 
orang-orang miskin pada hari itu, dari yang diwajibkan dari jenis jenis yang mencukupi, ada tiga pendapat :

1) Makanan pokok yang menguatkan di suatu negara. Pendapat ini yang dianggap paling sahih menurut Jumhur Ulama'.

2) Menguatkan dirinya, maksudnya bisa mengenyangkan bagi orang-orang miskin.

3) Boleh memilih di antara jenis jenis tersebut.

Para Ulama' menyatakan, jika kita mewajibkan makanan pokok, yang menguatkan dirinya atau di suatu negara, lalu ia beralih kepada yang lebih buruk, maka hal itu dianggap tidak sah. Tetapi jika beralih kepada yang lebih baik maka hal itu diperbolehkan dengan kesepakatan para ulama'. Jika kita utamakan adalah yang menjadi makanan pokok bagi dirinya, sedang yang pantas bagi dirinya adalah gandum, tetapi karena kikir, maknan utamanya adalah sya'ir maka wajib baginya mengeluarkan gandum. Apabila yang layak baginya sya' ir, tetapi ia bersenang-senang dengan makanan pokok gandum, maka menurut pendapat yang sahih, boleh baginya mengeluarkan sya'ir. Apabila kita mewajibkan makanan pokok di suatu daerah, sedangkan orang-orang makanan pokoknya beraneka ragam, tidak ada yang menonjol maka orang boleh mengeluarkan apa saja tetapi yang lebih utama ia mengeluarkan yang terbaik (Barkah, dkk. 2020: 59).

\section{f. Hikmah Zakat Fitrah}

Adapun hikmah bagi orang yang membayar zakat fitrah dan bagi orang yang menerimanya yaitu :

Pertama, yaitu berhubungan dengan orang yang berpuasa pada bulan Ramadhan. Kadangkala di dalam berpuasa itu orang-orang terjerumus pada perkataan dan perbuatan yang tidak ada manfaatnya, padahal puasa yang sempurna itu adalah puasa pula lidah dan anggota tubuhnya. Tidak diizinkan bagi orang yang berpuasa, baik lidahnya, telinganya, matanya, hidungnya, tangannya maupun kakinya mengerjakan apa yang dilarang oleh Allah dan Rasulnya, baik ucapan maupun perbuatan.

Kedua, yaitu berhubungan dengan masyarakat, menumbuhkan rasa kecintaan kepada orang-orang miskin dan orang-orang yang membutuhkannya. Hari raya adalah hari gembira dan bersuka cita tahunan, karenanya kegembiraan itu harus ditebarkan kepada seluruh anggota masyarakat Muslim.

Keempat, yaitu membersihkan diri dari sifat kikir dan akhlak yang tercela, serta mendidik diri agar bersifat mulia dan pemurah dengan membiasakan membayarkan amanat kepada orang yang berhak dan berkepentingan.

Kelima, yaitu sebagai ucapan syukur dan terima kasih atas nikmat kekayaan yang diberikan kepadanya. Tidak salah lagi bahwa berterima kasih yang diperlihatkan oleh yang diberikan kepada yang memberi salah satu kewajiban yang terpenting menurut ahli kesopanan.

Keenam, guna menjaga kejahatan-kejahatan yang akan timbul dari orang miskin dan orang yang susah. Betapa tidak Kita lihat sendiri sehari-hari, betapa hebatnya perjuangan hidup, berapa banyak orang yang baik-baik, tetapi menjadi penjahat besar, lalu merusak masyarakat, bangsa dan negara.

Ketujuh, menanamkan nilai-nilai pendidikan, keadilan dan kesejahteraan sehingga diharapkan mampu memecahkan problem kemiskinan, memeratakan keadilan dan meningkatkan kesejahteraan bangsa dan negara (Mardani, 2016 : 351). 
Kedelapan, dapat mensucikan diri pribadi dari kotoran dosa, memurnikan jiwa, peka terhadap rasa kemausiaan dan mengikis sifat kikir serta serakah. Dengan begitu, akhirnya tercapai suasana ketenangan batin karena terbebas dari tuntutan Allah dan kewajiban kemasyarakatan (Sudarsono, 2008: 260).

\section{Hasil Sosialisasi}

Dari sosialisasi yang narasumber dan panitia kepada santriwati Pondok Pesantren Madinatul Quran desa Betung Ogan Ilir, diharapkan para santriwati dapat memahami materi tentang zakat fitrah secara terperinci. Dengan kegiatan tersebut semoga narasumber dan peserta mendapat wawasan tentang zakat fitrah diantaranya sebagai berikut :

1. Peserta santriwati pondok pesantren Madinatul Quran desa Betung bisa memahami zakat firah secara terperinci.

2. Para santriwati pondok pesantren Madinatul Quran desa Betung bisa memahami tentang mustahiq dan ukuran zakat fitrah yang dikeluarkan.

3. Mengenalkan waktu-waktu membayar zakat fitrah dan jenis benda yang dikeluarkan.

4. Para peserta sosialisasi bisa memahami hikmah pembagian zakat fitrah.

5. Para peserta sosialisasi tanya jawab dan diskusi tentang zakat fitrah.

\section{Dokumentasi Kegiatan Sosialisasi}

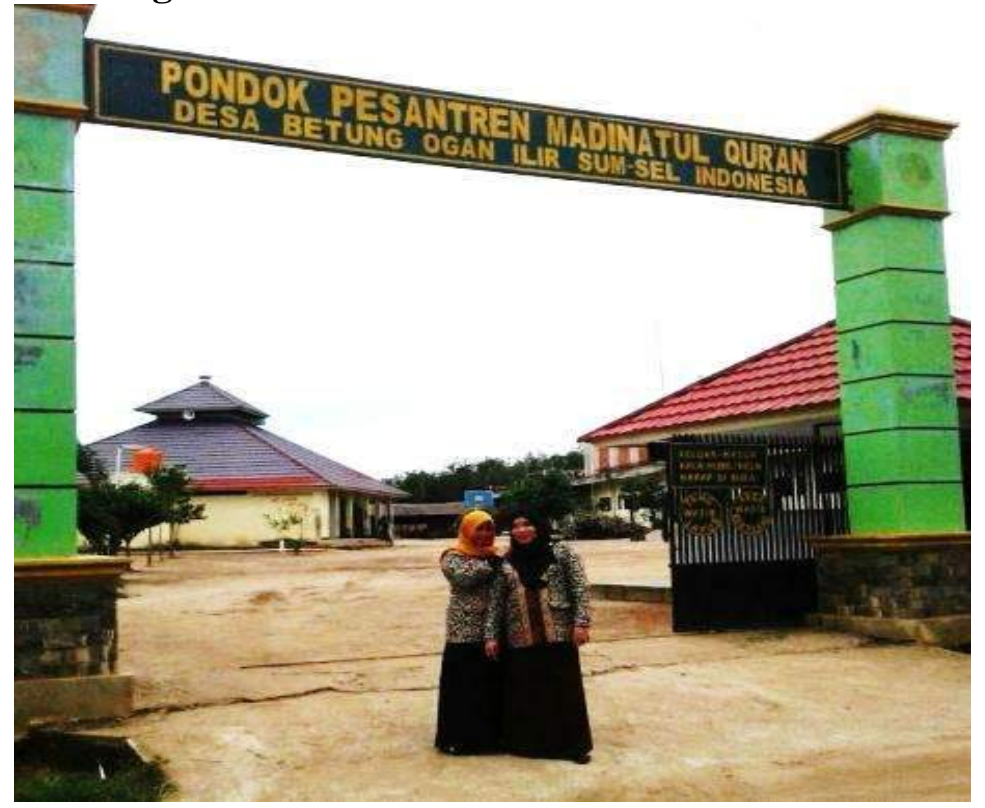




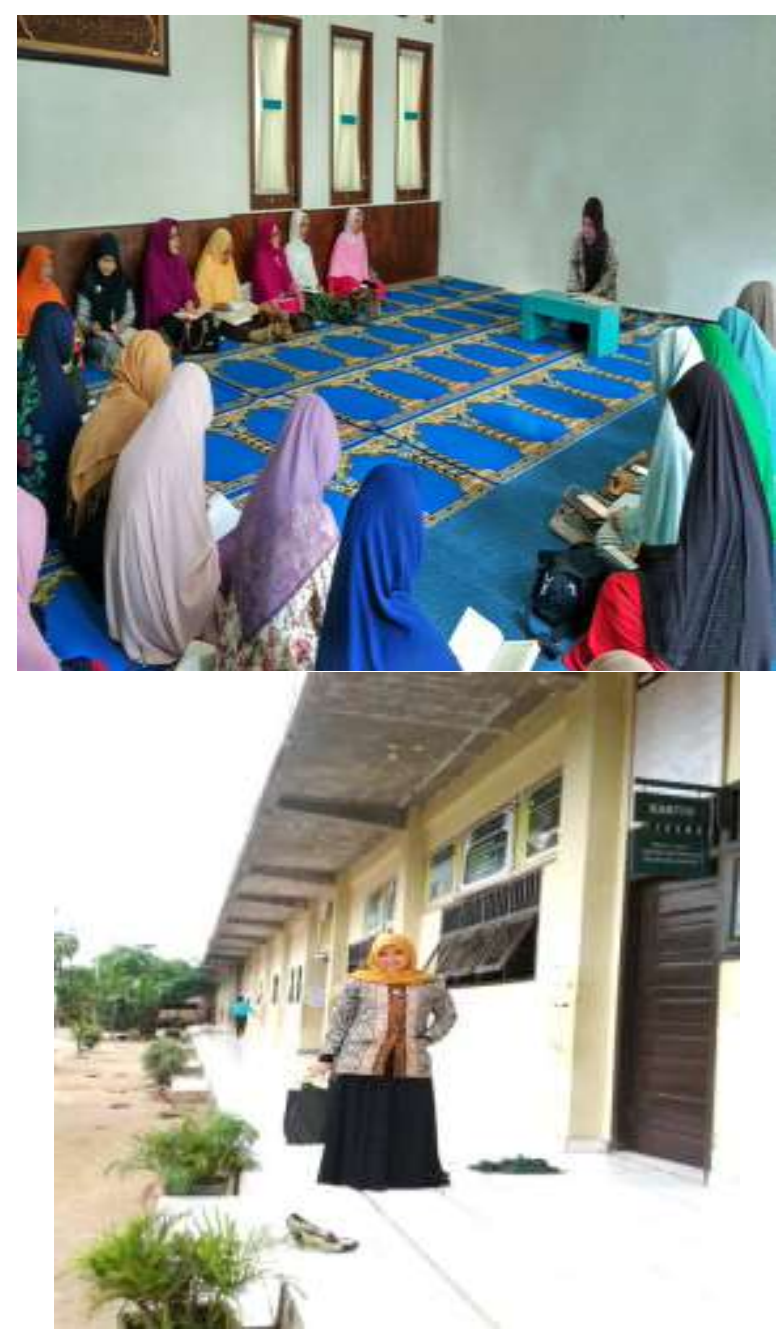

\section{Simpulan}

Berdasarkan beberapa kegiatan yang telah narasumber beserta panitia lakukan pada pengabdian masyarakat tentang zakat fitrah di pondok pesantren Madinatul Quran desa Betung Ogan Ilir maka dapat diambil beberapa kesimpulan

1. Kegiatan ini sangat bermanfaat bagi peserta sosialisasi zakat fitrah, santriwati membutuhkan tambahan pengetahuan tentang penerapan pembagian zakat fitrah secara benar menurut ajaran Islam.

2. Kegiatan pengabdian masyarakat ini juga membantu para peserta sosialisasi tentang pengertian zakat fitrah, syarat zakat fitrah, dalil tentang kewajiban zakat fitrah, waktu-waktu membayar zakat fitrah, mustahiq zakat, jenis-jenis benda yang wajib dizakatkan, dan hikmah zakat fitrah.

3. Meningkatkan pengetahuan santriwati bahwa dengan adanya pembagian zakat fitrah yang adil dan merata akan memperbaiki perekonomian seluruh masyarakat.

4. Para peserta sosialisasi memahami kadar zakat fitrah yang wajib dikeluarkan untuk asnaf yang delapan.

5. Seluruh santriwati pondok pesantren Madinatul Quran yang mengikuti sosialisasi zakat fitrah melakukan diskusi dan tanya tanya secara menyeluruh tentang zakat fitrah. 


\section{Daftar Pustaka}

Barkah, Qodariah dkk. 2020. Fikih Zakat, Sedekah, dan Wakaf. Jakarta : Prenada Media Group.

Chaudhry, Muhammad Sharif. 2016. Sisitem Ekonomi Islam: Prinsip Dasar. Jakarta: Prenada Media Group.

Fakhruddin. 2008. Fiqh dan Manajemen Zakat di Indonesia. Malang : UIN Malang Press. Hal. 40.

Huda, Nurul dan Mohamad Heykal. 2013. Lembaga Keuangan Islam: Tinjauan Teoritis dan Praktis. Jakarta : Kencana.

Mardani. 2016. Fiqh Ekonomi Syariah Fiqh Muamalah. Jakarta : Kencana.

Mujahidin, Akhmad. 2014. Ekonomi Islam: Sejarah, Konsep Instrumen, Negara dan Pasar. Jakarta: Rajawali Pers.

Rozalinda, 2016, Ekonomi Islam Teori dan Aplikasinya pada Aktivitas Ekonomi. Jakarta : Rajawali Pers.

Saprida. 2015. Fiqih Zakat Shodaqah dan Wakaf. Palembang : Noer Fikri.

Sudarsono, Heri. 2008. Bank dan Lembaga Keuangan Syariah: Deskripsi dan Ilustrasi. Yogyakarta : Ekonisia. 
Sosialisasi Pengenalan Zakat Fitrahterhadap Santriwati

Pondok Pesantren Madinatul Duran

Saprida 